This item was submitted to Loughborough's Research Repository by the author.

Items in Figshare are protected by copyright, with all rights reserved, unless otherwise indicated.

\title{
The Bible and its exegesis in Aphra Behn's “An essay on translated prose” (1688)
}

PLEASE CITE THE PUBLISHED VERSION

https://doi.org/10.1080/09699082.2020.1748810

PUBLISHER

Taylor \& Francis (Routledge)

VERSION

AM (Accepted Manuscript)

PUBLISHER STATEMENT

This is an Accepted Manuscript of an article published by Taylor \& Francis in Women's Writing on 3 July 2020, available online: http://www.tandfonline.com/10.1080/09699082.2020.1748810.

LICENCE

CC BY-NC-ND 4.0

\section{REPOSITORY RECORD}

Gill, Catherine. 2020. "The Bible and Its Exegesis in Aphra Behn's "an Essay on Translated Prose" (1688)". Loughborough University. https://hdl.handle.net/2134/12445562.v1. 


\title{
The Bible and its Exegesis in Aphra Behn's "An Essay on Translated Prose" (1688)
}

Catie Gill

\begin{abstract}
By assessing Aphra Behn's preface to Bernard de Fontenelle's Entretiens sur la pluralité des mondes, which was published as "An Essay on Translated Prose" (1688), this article marks a subtle but profound shift in the understanding of how Behn engaged with the Bible. Firstly, it establishes that Behn drew on material that fused scientific theory and Bible analysis, specifically John Wilkins's $A$ Discourse Concerning a New Planet (1640). Secondly, it explores how Behn deployed biblical quotation, and paratext, and explains the significance of the edition that she consulted. Thirdly, it proposes that Behn accessed Bible Commentaries and "annotations" that were published widely throughout the seventeenth century as scholarly guides to scripture's meaning. This article thereby situates Behn in relation to the resources and thinkers that facilitated her as she produced biblical exegesis.
\end{abstract}

Aphra Behn translated several French authors into English during her career, but only Bernard de Fontenelle's Entretiens sur la pluralité des mondes (in English, A Discovery of New Worlds) explains her purpose in bringing a text to print. ${ }^{1}$ Fontenelle was a populariser of astronomy's finding that our solar system is as Copernicus, Galileo, and Kepler had identified: heliocentric. ${ }^{2}$ In her preface to the translation, Behn explains that her aim is to "take his part". ${ }^{3}$ Described on the book's title page as "An Essay on Translated Prose", this preface has attracted considerable attention in the field of translation studies, and has become a significant marker of the inspiration Behn took from French writing. ${ }^{4}$ I want to focus here not on the section of "Translated Prose" so well explored in such studies, but on the quite lengthy set of examples from the Bible that she discusses when introducing Fontenelle's main scientific ideas. ${ }^{5}$ My goals are to show that Behn's interest in the Bible merits further investigation, and to identify some likely sources of her knowledge of scripture.

There is now widespread recognition that Behn's interest in science is broader than the heliocentrism of "Translated Prose", as is evident in her earlier stories, plays and poems. Behn or her characters comment on matters as varied as Harvey's propositions about the circulation of the blood, Lucretian atomism and its development by Descartes, and the astronomy of heliocentrism that will be the main theme of this discussion. ${ }^{6}$ Behn's preface to Fontenelle is therefore not without precedent in her earlier work. Due to its serious engagement with heliocentric theory, "Translated Prose" may nevertheless signify her deepening appreciation of the sciences.

In terms of the theory that is made central to both Fontenelle's Entretiens and "Translated Prose", Behn insists that the heliocentric model of the solar system is underpinned by reliable science. She aligns Fontenelle with the "best Mathematicians in Europe", and assures her readers that the Copernican model is "better" than earlier explanations that concluded that the sun orbits the earth (78). Rather than developing this area of agreement with Fontenelle, however, Behn shifts attention to their differences, including the fact that Entretiens omits religion from its account of the solar system. ${ }^{7}$ From there, through a series of well-chosen examples, Behn sets out to assess whether the scriptures are "as much for Copernicus as Ptolemy" (78-9), assigning the Bible a prominence denied by Fontenelle.

Since the Bible-centred discussion of "Translated Prose" is indicative of Behn parting ways with Fontenelle, rather than comparing the two, I shall address her debt to an earlier writer, John Wilkins. His works from the 1630s "were never repudiated, and frequently republished" during the seventeenth century. ${ }^{8}$ Taking the lead from Janet Todd's identification in her Works of Aphra Behn of how much the two authors had in common, the focus here will be on the section of Behn's discussion where Wilkins's influence is clearest: her exegesis of the Bible passages Psalm 19, Isaiah 38, and Joshua 10. ${ }^{9}$ Wilkins's works are 
very important to the general history of the relationship between seventeenth-century science and religion. My intention here is to focus on the particular question of the extent to which Wilkins's Bible readings had an impact on Behn's thinking about religion in her "Translated Prose", considering them alongside her other likely sources for the ideas she explores.

As I shall show, Behn's exercises in scriptural analysis are no less specialised than her scientific knowledge. It was impossible to comment on the scripture in the period in which Behn was writing and be disinterested in, or unaware of, the attacks and defences of scripture in the field of science. ${ }^{10}$ It is also significant to note that when Behn writes her analysis of Bible passages, Wilkins's guidance only accounts for the early examples in "Translated Prose", when she is discussing heliocentrism. For Todd and most later scholars there is less certainty about the later sections' Bible criticism which relates to the field of Chronology - a deficit I begin to address. Even less attention has been given to the edition of the Bible that was to hand when Behn was writing "Translated Prose" than to Chronology. And yet, if we are to understand the value of scripture to Behn, the Cambridge Bible (her point of reference) must be part of the analysis. An enhanced understanding of "Translated Prose" can be achieved by placing Behn in relation to writers such as Wilkins, works such as the Cambridge Bible, and also the godly-written and widely available Bible companions, published contemporaneously as Annotations and Commentaries on scripture, which I will show offer much in terms of biblical explication. "Translated Prose" hence illustrates Behn's interest in biblical as well as scientific debates.

\section{I) Heliocentrism: Behn's Interpretation of Psalm 19, Isaiah 38, and Joshua 10}

The Bible is neither systematic nor especially coherent in the ways that it engages with matters of natural philosophy. What Behn draws attention to are a series of intriguing pointers, rather than absolute truths, in scripture's accounts of the way that the sun and the earth relate to each other in the physical space of the universe. Sometimes, the language of the Bible seems to imply that the Heavens are the mobile vault that the Ptolemaic system expounded, which rotates daily around a fixed body, the earth. Other passages do not seem too dissimilar to Copernicus' De Revolutionibus (1543), or, as Behn explains, at least could indicate that heliocentrism does not "contradict the holy Scriptures" (84). As part of her analysis, Behn explores the section from Psalm 19 that reads: "The heavens declare the glory of God; and the firmament sheweth his handywork. [...] In them hath [God] set a tabernacle for the sunne, which is as a bridegroom coming out of his chamber, and rejoyceth as a strong man to runne a race" (19: 1-5). This Psalm seems to figure a geocentric rather than a heliocentric universe through the way it describes the sun in the heavens, so is antithetical to Behn's scientific analysis. She nevertheless defends her Copernicanism against the geocentric implications of this Psalm, and against other passages such as Isaiah 38 and Joshua 10 that raise different questions about the earth's diurnal turning. Isaiah 38, for instance, is a Bible passage that describes a shadow on a sundial going anti-clockwise, contrary to expectation. Behn considers which of the contrasting accounts of this event is to be believed at this point. Meanwhile, in Joshua 10, through extended sunlight or brighter moonlight (Behn tries to distinguish which), the Israelites fight on to defeat their enemies and so secure a victory that seems to be aided by God, through nature. Joshua's request "Sunne, stand thou still upon Gibeon" (10: 12), Behn argues, poses questions about the natural laws governing a heliocentric universe. "Translated Prose" also establishes the scripture's "design", therefore some matters of general scientific principle will be discussed first in this this article, before turning to examine Behn's treatment of her examples from Isaiah, Joshua, and the Psalm (79).

Behn makes clear she understands how the passages she has selected not only explain natural phenomena, but also uncover a general principle, or "design" in the Bible, sufficient 
to defend Copernicanism (79). "Translated Prose" is selective exegesis, and the brevity of the piece means she omits some intriguing passages from scripture, yet she has nevertheless chosen some thought-provoking examples. ${ }^{11}$ "Translated Prose" deciphers these passages, and further asserts that the Bible is of limited use as a guide to heliocentrism, in that it provides clues rather than empirical observation as to the organisation of the cosmos. Behn insists, therefore, that the Bible is not a practical guide to the solar system, as "the design of the Bible was not to instruct Mankind in Astronomy, Geometry, or Chronology" and moreover "the holy Scriptures, in things that are not material to the Salvation of Mankind, do altogether condescend to the vulgar Capacity" $(79,85)$. These comments, which might draw on Wilkins, as is discussed below, explain that even if the Bible seems to contradict Copernicus, it is because scripture was not designed primarily as a guide to natural phenomena, but to bring the people (the "vulgar") to greater faith.

One of the characteristics of the period when Behn was writing "Translated Prose" was that readers with very different positions on the Bible could present an analysis of scripture that looked remarkably similar. ${ }^{12}$ Certainly, not all of the people writing about the Bible in the 1680s wanted to preserve its cultural authority, and some indeed might actively have wanted to harm its reputation. Behn was operating within a culture where a vanguard of freethinkers, religious rationalists, and deists had much to say on the Bible's utility. ${ }^{13}$ It is therefore useful that the tone of "Translated Prose" has been subject to analysis, such as in Robert Markley's insistence that Behn is "wry and even corrosive" when dealing with scripture. ${ }^{14}$ Less useful are relatively uncritical assumptions about Behn's wider knowledge of Freethinking. It is fairly common practice to write about "Translated Prose", Entretiens, and another of Fontenelle's works - Histoire des Oracles (The History of Oracles, 1688) - as though they are neatly interlinked. However, it is worth noting, the new Cambridge edition does not attribute Oracles to Behn. ${ }^{15}$ If she was not the translator of this second text by Fontenelle, then there are two options: she could have been familiar with Oracles as a reader, or might not have known it at all. We cannot assume Behn's familiarity with Fontenelle beyond Entretiens until the provocative findings from the Cambridge team have been further explored. I therefore omit Oracles from this account.

With regards to the analysis of scripture, an early question in the account of heliocentrism given in "Translated Prose" relates to the difficulty of squaring Copernicanism with the ancient belief that the earth was the centre of the cosmos, and so of God's design. Psalm 19, as aforementioned, states that the sun is mobile, in that it returns to its home (or "tabernacle") each day: "the sunne [...] is as a bridegroom coming out of his chamber, and rejoyceth as a strong man to runne a race" (Psalm 19: 1-5). To Behn, this passage is little obstacle to the Copernican model, because even though the Psalm seems to show the sun, rather than the earth, in transit, she twice declares the language "Allegorical" $(82,84)$. Behn does little more with this passage, but for our purposes what is important is what it reveals she knows: that by tradition, exegetes look to categorise passages according to whether they are literal, allegorical, moral, or prophetical. Behn therefore decentres the earth both accurately and persuasively merely on a point of language.

Behn's earlier work, especially the poetry, does evoke the spheres so as to establish her characters' place in the universe. ${ }^{16}$ For instance, her "A Pindaric on the Happy Coronation of [...] James II" includes an address to "Ye little Gods that tun'd the Spheres", and a poem to "Lysander at the Musick-Meeting" celebrates "When the Tun'd Spheres Glad all the Heav'ns around". ${ }^{17}$ Behn's language is figurative rather than literal in these poems, and she therefore reinforces the sense that geocentrism is outdated. The spheres are a rhetorically pleasing idea, but Behn is not offering Ptolemy's cosmos as scientifically verifiable. 
When Behn's "Translated Prose" turns to discussing Isaiah 38 she presents a similar conceptual challenge to the heliocentrist, with an example that has the potential to prove Ptolemy's geocentrism. The important Bible moment is the passage when Hezekiah witnesses a shadow move anticlockwise. In her overview, Behn quibbles over the ambiguity of scripture: does the sun or the shadow from the sun turn backwards ten degrees on the ailing Hezekiah's sundial? Behn establishes an important distinction. If the main text of Isaiah is right, then the "sunne returned ten Degrees" (38: 10); but if the marginalia in the Cambridge Bible are correct, Behn notes "the Shadow returned Ten Degrees by the Sun" (84). Behn examines both, main and paratext, seemingly with the translator's eye for disputed meaning. Behn therefore undermines Hezekiah's testimony through highlighting the Bible's ambiguity, but with the aim of showing that this part of Isaiah does not prove geocentrism.

Signs from God such as that seen by Hezekiah, indeed, are often shown to be rather insubstantial in Behn's wider work. Her "Congratulatory Poem to her Most Sacred Majesty" proposes that the birth of James and Mary's son is a "Mighty BLESSING", even evidence of God's "Wond'rous WORK"; furthermore, the news is of such import that it that brings "The World's vast Bus'ness" to "a Stand". Yet, monumental as the language of celebration seems, Behn claims no other witnesses than herself to this apparent signal from God. ${ }^{18}$ Hezekiah's sign, like the one from her own time accompanying the royal nativity, appears in fact to be both inconclusive and subjective and so offers little resistance to the Copernican model that Behn is seeking to endorse.

As Behn proceeds through "Translated Prose", she requires a ballast of scientific and exegetical knowledge to inform her analysis of the scripture. In fact, the third of her examples, Joshua 10, makes use of information beyond that which the generalist reader could reasonably infer from the Bible, such as specific details of the lunar cycle, and the distance between habitations in the holy land where Joshua was battling his enemies and his people were building a community (83). ${ }^{19}$ She certainly found the empirical support for her argument on Jewish ancient history primarily in John Wilkins's A Discourse Concerning a New World (1640); and indeed, she had mentioned his discoveries a year earlier, in The Emperor of the Moon (1687). ${ }^{20}$ Wilkins, in turn, obtained some of his evidence from the theologians Alonso Tostado (1410-55) and Nicolaus Serarius (1555-1609), whom he references for their discussions of Joshua $10 .{ }^{21}$

The ways in which the authors' texts overlap is clearer if chronology is followed, so Wilkins's mid-century perspective will be first assessed, before turning to Behn's engagement with what Margaret Ferguson has called the "potentially dangerous matters of religion and science" circulating in the late seventeenth century. ${ }^{22}$ Just as Behn with some ease dispatched the figurative language in Isaiah and the Psalm, so Wilkins understood that the Bible need not be taken literally. He demonstrated this when assessing how the Moabites (2 Kings 3: 22) described the colour of the sea being "as red as blood"; he discounted their inference that there was blood in the water, and identified the cause: "[the sun's low] beames make the waters appeare very red". ${ }^{23}$ The two authors, Behn and Wilkins, clearly shared a resistance to reading the Bible literally.

Wilkins's intention is to demonstrate that heliocentrism is not contrary to the scripture, but compatible with it. In acknowledgement of Wilkins's unificatory methods, Katherine Calloway has rightly identified his facility for "intellectual peace-making", which applies as much to ideas as to people. ${ }^{24}$ A Discourse Concerning a New World might not strike a reader as placatory, or not initially, as Wilkins is unflinchingly critical of geocentrists. Anthony Ross, an intellectual opponent, is reminded that he is in the minority in following Ptolemy, as "Very many" of Wilkins's peers "affirmed our Earth to be one of the Planets, and the Sunne to be the Center of all". ${ }^{25}$ Wilkins further ensures that his science is grounded in robust demonstration that relies on logic and empirical data for its Galileo- and 
Kepler-informed analysis. If the earth were immobile and the heavens mobile, then the sun, planets and other stars would have to move at an incredible speed. ${ }^{26}$ The evidence for the Copernican cosmos is consequently given weight through Wilkins's careful explanations. As a unifier of the different discourses of science and scripture, Wilkins maintains " 'Tis probable that the Sunne is the centre of the World" and examines the "particular Scriptures, which are commonly urged to prove the motion of the Sun or Heavens" before moving on to "further illustration". 27

Some of the passages Wilkins subjects to subtle refutation are advanced in concert with a proposition: "'tis besides the scope of the old Testament or the new, to discover any thing unto us concerning the secrets of Philosophy [i.e. science]". ${ }^{28}$ This precept has already been observed in Behn when she discussed the "design" of the Bible $(79,85)$. In fact, Wilkins only makes the statement that the Bible is not intended to serve as a textbook on Astronomy having earlier cited John Calvin's endorsement of this idea. Despite the credibility of underpinning his argument with a Church worthy, a gap is opening up between different kinds of truth-claim: to reveal that the Bible is not infallible on Astronomy, only on faith. Richard H. Popkin describes a downgrading of the claims made in relation to the Bible in the mid-century as "the commonsensical, practical solution to the sceptical crisis". ${ }^{29}$ Wilkins exemplifies this "solution", seeking neither to remove the supernatural agency of God from the account of the universe, nor to concede on his Copernicanism; he aims instead to renew the search for the ways in which religion and science can dovetail. His merging, however, does tend to gloss over contradictions. ${ }^{30}$

As noted by Ferguson, Behn's contemporaries might continue to have difficulties "believing in a scientific system that counters the evidence of a stationary earth and a moving sun given by the body and particularly by the human eye". ${ }^{31}$ These reservations would impact on how both heliocentrism and Fontenelle's representation of this theory in Entretiens were received. Fontenelle, who focusses solely on Copernicanism, says "not a Word" of God, and, according to Behn, seems "almost [...] to be a Pagan", writes science without reference to the Bible (77). Behn, instead, chooses not to corroborate Fontenelle's materialism, but to deploy Wilkins's older framework of fusing the Bible's descriptions of the cosmos with empirical observations. This is a clear indication of the continued persuasiveness of Wilkins's approach. ${ }^{32}$ The simplest explanation for this decision is that it enabled Behn to engage with her contemporaries through examples that they would understand, easing forwards the scientific ideas that even as late as 1688 still had the power to unnerve some "cosmological conservatives", to use David Cressy's term. ${ }^{33}$

There are other possible explanations, however, of Behn's approach to biblical criticism. One effect of Behn's act of restoring the Bible to a position of centrality is that it raises the stakes in terms of how useful a reference point it is for natural philosophers. Perhaps Behn is subjecting the Bible to more pressure than it can feasibly withstand, in order to make a point that seems closer to the freethinker Fontenelle than to the relatively orthodox Wilkins. One instance of the pressure on scripture is when Behn describes Joshua 10's events at Gibeon, the day the sun stood still. Behn observes: "according to the System of Ptolemy, where was the necessity of the Moon's standing still? [... W] here was the Loss or Disorder in Nature [i.e. miracle]?" (83). This is to say that she makes the miracle proof of heliocentrism, whereas acceptance of the miraculous, since at least Augustine, is more usually an indication of the faithful belief in God. ${ }^{34}$ Behn's fusion of science and religion, while seeming to defer to religious expectation, endorses a point that could provoke incredulity. As Ellenzweig explains, "Behn asserts [...] that the miracle in Joshua, in fact, involved more, not less, supernatural intervention than Scripture reports", so her expansion from the scripture has increased the complexity of the passage. ${ }^{35}$ This is an example of Behn setting a hare running, 
which, notably, negates hers and Wilkins's point that the Bible's "design" is to prove matters of faith, not Astronomy (79).

I contend that there is no clear way at a textual level to address whether Behn was putting the Bible to good effect by fusing the scripture and science in the manner of Wilkins, or subtly undermining it. The tone of her comments in relation to the heliocentric miracle seems to be wry. How important, though, is tone when set against the clear evidence that "Translated Prose" uses the method of the relatively orthodox Wilkins of fusing the scripture and science, and does so repeatedly? Because these conceptual and essentially hermeneutic issues need further exploration, the final part of this article will turn towards Behn's other scriptural examples. Some assertions in the Bible are not factually verifiable, and indeed lead to discrepancies, such as whether Solomon ruled for 40 years or significantly longer. Behn focussed on this example, but so, too, did many of her contemporaries. Some, indeed, presented their efforts to explore Solomon's chronology as the work of the orthodox in search of truth, and seem not to want to question the Bible's dependability. However, the unreliability of scripture on this point inevitably emerges. Through this example, and particularly through a spelling in Behn's quotation of a passage in Joshua 10, there is also evidence of the edition of the Bible Behn had to hand when writing. Both of these factors develop our understanding of her attitudes to scripture.

\section{II) Behn as Interpreter of the Chronology of Solomon}

Robert Markley is one of the few critics to have paid attention to the chronology section in a tremendously valuable account of "Translated Prose". His work rectifies the relative silence on this topic, making it clear that chronology is potentially as incendiary as heliocentrism. ${ }^{36}$ Chronology was, indeed, not an especially highly regarded area of Bible scholarship in the seventeenth century. ${ }^{37}$ "Translated Prose" fixes on the tenure of the Israelites' first Kings, and particularly Solomon. Behn cannot make a specific observation (from 1 Kings 11: 42, which says Solomon ruled for 40 years) fit with the ascribed reigns of kings preceding and post-dating him, nor with other details that scripture provides about his life (79-82). Behn has found another textual crux to explore and exploit, one that is not discussed in Wilkins's $A$ Discourse Concerning a New World. Yet her commentary at this point in "Translated Prose" requires the same sort of biblical expertise to underpin her argument as do the sections on heliocentrism. The question is, then, where did she acquire that expertise?

No single author or work answers this question; rather, a probable solution can be supplied from looking to a body of resources that circulated in the seventeenth-century public sphere to explain the Bible's meanings. These were known as Bible Commentaries, or "annotations", and as Ian Green observes, "by 1642 no book of the Bible was without some exposition of the whole or part in English, and by 1668 the slight earlier preponderance of works on the Old Testament had given way to a clear dominance of works on the New". ${ }^{38}$ The value of Bible Commentaries to Behn is apparent here, as they too deal with the imprecision of the scripture with regards to the dates of Solomon's reign. In fact, reading a Commentary alongside the Bible is like having access to footnotes so detailed that first they complement, then exceed the text itself. It is not necessary to read from first to last page with a Commentary, so it has a very practical appeal to the time poor. If Behn was like many others in her culture in being practised in the arts of "information retrieval, active reading, [and] reading in parts", then she would have found the Commentaries hugely valuable. ${ }^{39}$

Given the necessary length-constraints on this argument, the significance of just two Bible Commentaries will be summarised. Sir Norton Knatchbull acknowledges, also on Solomon's indeterminate reign, "This place [Acts 13: 20] saith Scaliger, is crux Chronologorum. The truth is, Interpreters also have not been a little vexed with it". ${ }^{40}$ Matthew Poole likewise summarises that "This Chronological difficulty, is too vast and 
comprehensive to be fully discussed here", in his Annotations on the Holy Bible (1683). ${ }^{41}$ Behn's comment in "Translated Prose" aligns with this frustration at inconclusivity: "It is not my present Business to reconcile this difference [i.e. in the figures given of Solomon's reign]; but I can easily do it" (80). Behn here seems to want to give the impression that the fault is neither with the Bible, nor with her comprehension, but that her argument needs to turn to other matters. She may, however, not be entirely innocent in focussing on an example so detrimental to scripture. Behn's exploitation of the Bible Commentaries' resources would be worth considering further, both for shared content and a shared approach to methods for responding to ambiguities in scriptural phrasing. ${ }^{42}$ One additional piece of supporting evidence that she might have been alert to the usefulness of Bible Commentaries is that Wilkins's A Discourse Concerning a New World also refers to them when discussing heliocentrism. In that, he was like the natural philosopher Thomas Browne, who used Commentaries to understand the natural world in works such as the bestselling Religio Medici. ${ }^{43}$

Finally, what evidence does "Translated Prose" supply of how Behn responded to the Bible as a material artefact? It is easy to assume that the words she transcribes are without interest, but several points can in fact be made in relation to how Behn engages with the text. Across all her quotations but one Behn is accurate, and indeed, her interest in the text and the marginal glosses (previously discussed) seems to show her working attentively. However, there is a single tantalisingly inconclusive instance of Behn intervening in the scripture itself. In the section of "Translated Prose" relating to Solomon, Behn quotes Acts 13: 17-22 verbatim, but writes of the Israelites leaving Egypt, "God [...] with an high Hand brought he them out of it" (79). In all editions of the Bible, Coverdale (1535), The Great Bible (1539), Geneva (1560), the Bishop's Bible (1602) and King James Bible (1611), as well as in the Cambridge Bible (1629; 1638), "Arm" not "Hand" appears. Of course, "Hand" and "Arm" are more or less synonymous, so the slip might be due to transcription fatigue. Even so, "High-handedness" meant "tending to the use of power or authority without regard for others," whereas "arm" has no such corollary $(O E D)$. This would be a felicitous slip for an impious writer to make, if seeking to intervene in the text and avoid detection.

It is usually not a simple matter to identify a writer's choice of Bible as there were so many on the market, but "Translated Prose" offers valuable evidence as to which version Behn had to hand. She is clear on several details: the size of her Bible ("small folio"), and the name of the printer ("Buck"). This indicates that she used a Cambridge Bible, and even more particularly corresponds to an issue date of 1629 or 1638 , as these were the press's only small folios. The printers, John and Thomas Buck, collaborated only once (1629), and when the next small folio was issued it was from the partnership of John Buck and Roger Daniel (1638); Behn's decision to refer to "Buck's" Bible (rather than Buck and Daniel) may be evidence that she possessed the 1629 edition. ${ }^{44}$ But it does not entirely rule out 1638 , and spelling is another important indicator. Behn transcribes a word that only came into usage in Cambridge Bible (1629). The word is "Ajalon", a different form from "Aialon" (and other variants) in the King James Bible (1611) (83). ${ }^{45}$ Both the 1629 and the 1638 Cambridge Bibles were regarded as an improvement on the King James Bible, and were surpassed only by F. S. Paris's Cambridge edition (1762) that would eventually supersede it.

\section{"I have adventur'd to say nothing, but from good Authority" (85)}

My article broadens our understanding of the intellectual landscape that shaped the approach to scripture in "Translated Prose" by teasing out the printed sources that were available to writers of Bible exegesis, and asking which of these works were read by Behn. She declares of her connection to Fontenelle that where his defence of heliocentrism is concerned she "cannot but take his part", yet her writing diverges from him in significant ways by fusing the 
Bible and science, like Wilkins (78). Once it is understood how dependent Behn was on Wilkins, a wealth of new material in the form of the Biblical Commentaries opens up as a credible explanation for how Behn, in Line Cottegnies's words, was able to present an "impressive display of biblical criticism". ${ }^{46}$ The Bible Commentaries were widely available by the late seventeenth century, and provided detailed and accessible levels of Bible scholarship, but they have not previously been suggested as a source for Behn's analysis of scripture in "Translated Prose".

It is clear from the above that Behn was an astute and independent reader. If she relied on the Commentaries, then this is not to say she did not also engage with the authors she explicitly claims to have accessed in preparing the argument for "Translated Prose". She mentions writers such as Josephus, Anthony Godean, and Thomas Burnet, focussing on each with varying degrees of acidity. She disputes with the "famous Historian" Josephus on his calculation of Solomon's reign, avers that Godean's chronology convinces not "so well as what I have said", and being hindered as a woman from full participation in scientific culture, she reserves a particularly barbed comment for Burnet in saying that his book appeals to "ingenious Men" $(81,82,85) .{ }^{47}$ Some of those named, most notably Josephus, wrote very lengthy and presumably hard to access works. While Behn may have had access to a library containing them, it is nevertheless very credible that the Bible Commentaries formed at least part of her reading.

As Juliette Cherbuliez remarks of Fontenelle, so it is true of Behn: "determinism" works to a writer's disadvantage as much as to their advantage.$^{48}$ In particular, as Cherbuliez observes, the history of the critical reception of Entretiens, the text that Behn's "Translated Prose" introduces, is one of both celebration and critique. Fontenelle garners applause when he is prescient, discontentment when conventional. Behn, likewise, has also been lauded for embodying the qualities of early eighteenth-century or Enlightenment thinking. ${ }^{49}$ A more effective way of understanding late seventeenth-century texts, I contend, is to embrace their on-the-cuspness, a reading brilliantly advanced in relation to Behn by Andrew Barnaby and Lisa J. Schnell. ${ }^{50}$ In common with Cherbuliez, Barnaby and Schnell, I find it is useful to be critical of our expectations of period. With respect to the Bible, we can infer that Behn perhaps thinks scripture a less useful source on science than she is prepared to say; but there is evidence that she relies on godly learning, even so. Once it is recognised that the orthodox Bible Commentaries were also critical of the Bible, and Behn used Wilkins more than Fontenelle to convey her heliocentrism, her place in late seventeenth-century culture is immediately more comprehensible.

\footnotetext{
Notes

${ }^{1}$ Paul Tallemant, François de La Rochefoucauld, Balthasar de Bonnecorse, Jean-Baptiste de Brilhac, and Bernard de Fontenelle. Several short works of Behn's are also translations, most notably her poem "The Golden Age"; see Poems upon Several Occasions (London: R. Tonson and J. Tonson, 1684, 1-12. Future research will no doubt establish additional important examples.

${ }^{2} \mathrm{He}$ is a populariser, as Nina Rattner Gelbart points out, because he was able to render scientific concepts comprehensible through every-day analogies. See "Introduction", in Bernard de Bovier de Fontenelle, Conversations on the Plurality of Worlds, ed. H.A. Hargreaves (Los Angeles: University of California Press, 1990), i-xxix (xx).

${ }^{3}$ Aphra Behn, "A Preface by Way of Essay on Translated Prose", in The Works of Aphra Behn, ed. Janet Todd, 7 vols. (London: Pickering, 1993), IV, 71-86 (78). All further references to this edition will be cited in-text.

${ }^{4}$ An early and significant overview is provided by Line Cottegnies, "Aphra Behn's French Translations", in The Cambridge Companion to Aphra Behn, ed. Derek Hughes and Janet Todd (Cambridge: Cambridge UP, 2004), 221-34. See also Elizabeth Spearing, "Aphra Behn: The Politics of Translation”, in Aphra Behn Studies, ed. Janet Todd (Cambridge: Cambridge UP, 1996), 154-77; Sarah Goodfellow, “'Such masculine strokes': Aphra Behn as Translator of A Discovery of New Worlds", Albion 28.2 (1996): 229-50; Violetta Trofimova, "French Influence on English Culture in the Second Part of the Seventeenth Century: Aphra Behn as a Creative
} 
Translator and Mediator between the Two Cultures", Cultura, Lenguaje y Representación/Culture, Language and Representation 4 (2007): 241-51.

5 There is no benefit to using the term "natural philosophy" to describe Astronomy, so "science" is usually used here to describe the field of study "Translated Prose" discusses.

${ }^{6}$ Alvin Snider, “Atoms and Seeds: Aphra Behn's Lucretius”, Clio 33.1 (2003): 1-24. Karen Bloom Gervitz, "Behn and the Science of Self", in The New Science and Women's Literary Discourse: Prefiguring

Frankenstein, ed. Judy A. Hayden (New York: Palgrave, 2011), 85-98. Also see Sara Read's article in this volume.

${ }^{7}$ Behn comments that Fontenelle has said "not a Word" on the Bible (77). Another main point of difference between the two is their attitudes to the plurality of worlds. In her farce The Emperor of the Moon, the science of Doctor Baliardo (a pluralist) produces much of the humour of the play. Contrastingly, Fontenelle's Entretiens treats plural worlds as a possibility. In Discovery, Behn omits Book VI of Entretiens, a point investigated as indicating the two authors' differing attitudes to gender in Christina Knellwolf King, Faustus and the Promises of the New Science c. 1580-1730: From the Chapbooks to Harlequin Faustus (Farnham: Ashgate, 2008), 11149 (146).

${ }^{8}$ David Cressy, "Early Modern Space Travel and the English Man in the Moon", American History Review 111.4 (2006): 961-82 (968).

${ }^{9}$ Wilkins, A Discourse Concerning a New World and Another Planet (London: John Norton and John Maynard, 1640), 43-5. This work was in print in two editions in 1684 as A Discovery of a New World, one published by John Rawlins and the other by T.M. and J.A.

${ }^{10}$ Kenneth J. Howell, God's Two Books: Copernican Cosmology and Biblical Interpretation in Early Modern Science (Notre Dame, IN: University of Notre Dame Press, 2004); John Brooke and Ian Maclean, eds., Heterodoxy in Early Modern Science and Religion (Oxford: Oxford UP, 2005).

${ }^{11}$ For instance, Genesis 1: 14-18, Psalm 8, Ecclesiastes 1: 4 on creation; Isaiah 40: 22, Job 22: 14, Job 37: 18 on the heavens; Psalm 19: 4-6, Psalm 50: 1, Psalm 103:2-3 on the sun's place in the cosmos.

12 Justin Champion, “'Directions for the Profitable Reading of the Holy Scriptures': Biblical Criticism, Clerical Learning and Lay Readers, c. 1650-1720”, in Scripture and Scholarship in Early Modern England, ed. Ariel Hessayon and Nicholas Keene (Aldershot: Ashgate, 2006), 208-30.

${ }^{13}$ See Sarah Ellenzweig, Fringes of Belief: English Literature, Ancient Heresy, and the Politics of Freethinking, 1660-1760 (Palo Alto, CA: Stanford UP, 2008), particularly "Behn, Fontenelle, and the Cheats of Religion". Ellenzweig's is the fullest account of Behn's irreligion to date. I find her argument unconvincing in its citing of Charles Blount as Behn's source on the Bible's design (66). In my view, Behn's source is Wilkins, who in turn draws on John Calvin.

${ }^{14}$ Robert Markley, "Global Analogies: Cosmology, Geosymmetry, and Skepticism in some Works of Aphra Behn", in Science, Literature and Rhetoric in Early Modern England, ed. Juliet Cummins and David Burchell (Aldershot: Ashgate, 2007), 189-212 (204).

${ }^{15}$ See volume VIII of The Cambridge Edition (forthcoming).

${ }^{16}$ See Ros Ballaster, “Taking Liberties: Revisiting Behn's Libertinism”, Women's Writing 19 (2012): 165-78.

${ }^{17}$ Aphra Behn, "A Pindarick Poem on the Happy Coronation of His Most Sacred Majesty James II”, in The Works of Aphra Behn, ed. Janet Todd, 7 vols. (London: Pickering, 1992-6), I, 200-21 (1. 12); “To Lysander at the Musick-Meeting", I, 94 (1. 27).

18 Aphra Behn, “A Congratulatory Poem to her Most Sacred Majesty”, in Works, ed. Todd, vol. I, 294-6 (11. 12, 29); also see Patricia Gael, "Kingship and Catholicism in Posthumous Representations of Charles II, 16851714," Seventeenth Century 29 (2014): 173-96.

${ }^{19}$ Behn comments "The Moon was at that time very near the Sun; and by Consequence was at that time either a day or two before her change, or a day or two at most after a new Moon; and then she is nearer to Body of the Sun, as to appearance, so could not assist the Children of Israel with light" (83). The knowledge being deployed here seems to have come directly from Wilkins, A Discourse Concerning a New World, Book II, 38-43.

${ }^{20}$ The Emperor of the Moon, in Works, ed. Todd, vol. VII, I.1.95-6.

${ }^{21}$ Quoting their Bible Commentaries, of which more presently. Wilkins, A Discourse Concerning a New World, Book II, 13, 24, 39.

${ }^{22}$ Margaret Ferguson, “'With All Due Reverence and Respect to the Word of God': Aphra Behn as Skeptical Reader of the Bible and Critical Translator", in Reading Women: Literacy, Authorship, and Culture in the Atlantic World, 1500-1800, ed. Heidi Brayman Hackel and Catherine E. Kelly (Philadelphia: University of Pennsylvania Press, 2008), 199-216 (206).

${ }^{23}$ Wilkins, A Discourse Concerning a New World, Book I, 75.

${ }^{24}$ Katherine Calloway, Natural Theology in the Scientific Revolution (London: Pickering and Chatto, 2014), 71$93(71)$.

${ }^{25}$ Wilkins, A Discourse Concerning a New World, Book I, 90; on severity to Ross, see Book I, 3. 
${ }^{26}$ Wilkins states 4,529,538 German miles per hour, which translates to a speed of more than 21 million miles per hour in modern measurements; ibid., Book II, 189. See also Barbara J. Shapiro, John Wilkins, 1614-1672 (Berkeley: University of California Press, 1969), 59-60.

${ }^{27}$ Wilkins, A Discourse Concerning a New World, Book II, 133; Book II, 35.

${ }^{28}$ Ibid., Book I, 32. Slightly later he observes: “Moses is there to handle the History of Creation. But 'tis certaine (saith Calvin) that his purpose is to treat only of the visible forme of the world, and those parts of it which might be most easily understood by the ignorant and ruder sort of people" (33). Wilkins could have encountered the same idea in Galileo. William E. Carroll, "Galileo Galilei and the Myth of Heterodoxy", in Heterodoxy in Early-Modern Science and Religion, ed. John Brooke and Ian Maclean (Oxford: Oxford UP, 2005), 115-44: "[If] some passages of Scripture were to sound contrary, we would have to say that this is due to the weakness of our mind, which is unable to grasp the meaning of the Scripture in this particular case" (126-7). ${ }^{29}$ Popkin, The History of Scepticism from Erasmus to Descartes, $2^{\text {nd }}$ edn (London: University of California Press, 1979), 147. See Wilkins's Of the Principles and Duties of Natural Religion (1675).

${ }^{30}$ Calloway, Natural Theology, 15-28.

${ }^{31}$ Ferguson, "All Due Reverence and Respect", 204.

${ }^{32}$ Behn takes her critique of Fontenelle still further when amending some of his scientific deductions.

Cottegnies, “Aphra Behn's French Translations", 227, notes that Behn corrects the focus of Entretiens to remove the implication that the moon traversed the sun. Ferguson, "All Due Reverence and Respect", 202, points out that Fontenelle's theory evolved over time, with his deepening scientific knowledge. See also Todd, The Secret Life of Aphra Behn (London: Pandora, 2000), 397.

${ }^{33}$ Cressy, "Early Modern Space Travel", 965.

${ }^{34}$ Augustine of Hippo, City of God, trans. Gerald G. Walsh, Demetrius B. Zema, S. J. Grace Monahan, and

Daniel J. Honan (New York: Image Books, 1958), Book XII, chapters 8-9 (512-18).

${ }^{35}$ Ellenzweig, Fringes of Belief, 65.

${ }^{36}$ Markley, "Global Analogies”, 189-212.

${ }^{37}$ Scott Mandelbrote, “"The Doors Shall Fly Open': Chronology and Biblical Interpretation in England, c. 1630-c. 1730", in The Oxford Handbook of the Bible in Early Modern England, c. 1530-1700, ed. Kevin Killeen, Helen Smith, and Rachel Willie (Oxford: Oxford UP, 2015), 176-95.

${ }^{38}$ Ian Green, Print and Protestantism in Early Modern England (Oxford: Oxford UP, 2000), 116. See also David Lyle Jeffrey, A Dictionary of Biblical Tradition in English Literature (Grand Rapids, MI: Eerdmans, 1992), especially the following chapters: "Historical Studies in Biblical Hermeneutics" (889-97), and "A Checklist of Biblical Commentaries Available to English Authors", 901-4.

${ }^{39}$ Jennifer Richards and Fred Schurink, "Introduction: The Textuality and Materiality of Reading in Early Modern England”, Huntington Library Quarterly 73.3 (2010): 345-62 (350).

${ }^{40}$ Norton Knatchbull, Annotations upon Some Difficult Texts (Cambridge: W. Graves, 1693), 128.

${ }^{41}$ Matthew Poole, Annotations upon the Holy Bible (London: Thomas Parkhurst, Dorman Newman, Jonathan Richardson, and others, 1683), annotating Kings 6: 1 (sig. 4D2r).

${ }^{42}$ A good match for Behn is the encyclopedic John Mayer; see Nicholas Keene, "Mayer, John," (ODNB). See also Marcus Walsh, Shakespeare, Milton, and Eighteenth-Century Literary Editing: The Beginnings of Interpretative Scholarship (Cambridge: Cambridge UP, 1997), 4-29. Walsh establishes that the origin of literary editing is Biblical Commentary.

${ }^{43}$ When Wilkins is discussing heliocentrism, he quotes Alonso Tostado (1410-55), and Nicolaus Serarius (1555-1609), using their Bible commentaries. Wilkins, A Discourse Concerning a New World, Book II, 13, 24 , 39. For Browne's use of commentaries, see Kevin Killeen, Biblical Scholarship, Science, and Politics in Early Modern England: Thomas Browne and the Thorny Place of Knowledge (Farnham: Ashgate, 2009), 71-107 (74).

${ }^{44}$ S. Herbert, ed., Historical Catalogue of Printed Editions of the English Bible, 1525-1961, rev. edn (London: British \& Foreign Bible Society, 1968), entry 1629, 1638.

${ }^{45}$ David Norton, A Textual History of the King James Bible (Cambridge: Cambridge UP, 2005), 227.

${ }^{46}$ Cottegnies, “Aphra Behn's French Translation”, 230.

${ }^{47}$ I omit Taquet from this list because her comment on him has a level of hearsay: "the learned Father [...] a Jesuite [...] I am told, has writ a large Course of Mathematicks" (78).

48 Juliette Cherbuliez, "Ways of Knowing: Fontenelle and Gender", in Teaching Seventeenth- and EighteenthCentury French Women Writers, ed. Faith E. Beasley (New York: Modern Language Association of America, 2011), 109-18 (110).

${ }^{49}$ Kroll, "Tales of Love and Gallantry", 575. Kroll's point is in relation to Oroonoko (1688).

${ }^{50}$ Andrew Barnaby and Lisa J. Schnell, Literate Experience: The Work of Knowing in Seventeenth-Century English Writing (New York: Palgrave, 2002), 159-96. I want to thank Mary Ann O’Donnell, Michael Ridley, the Keele Interdisciplinary Early Modern Seminar, and colleagues at Loughborough for commenting on my work. 
Catie Gill is a lecturer in early-modern writing at Loughborough University. Her publications include Women in the Seventeenth-Century Quaker Community (Ashgate, 2005), Theatre and Culture (editor, Ashgate, 2010) and, with Michele Lise Tarter, New Critical Studies on Early Quaker Women (Oxford, 2018). She became curious about Aphra Behn and religion while working on conference papers about Restoration scepticism; this article is her first from this new research interest. Forthcoming work will appear in A Companion to the Cavendishes (ed. Hopkins and Rutter), and People and Piety (ed. Clarke and Daniel).

c.j.gill@lboro.ac.uk 